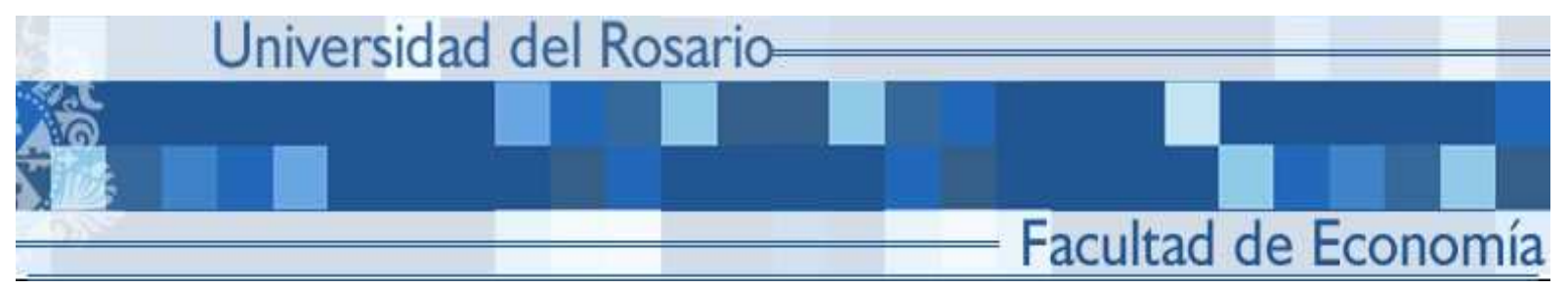

DON'T MAKE WAR, MAKE ELECTIONS FRANCHISE EXTENSION AND VIOLENCE IN XIXTH-CENTURY COLOMBIA

Leopoldo Fergusson

Juan F. Vargas

No. 135

Marzo de 2013 


\title{
Don't Make War, Make Elections Franchise Extension and Violence in XIXth-Century Colombia*
}

\author{
Leopoldo Fergusson ${ }^{\dagger} \quad$ Juan F. Vargas ${ }^{\ddagger}$
}

March 1, 2013

\begin{abstract}
This paper studies the effect of strengthening democracy, as captured by an increase in voting rights, on the incidence of violent civil conflict in nineteenth-century Colombia. Empirically studying the relationship between democracy and conflict is challenging, not only because of conceptual problems in defining and measuring democracy, but also because political institutions and violence are jointly determined. We take advantage of an experiment of history to examine the impact of one simple, measurable dimension of democracy (the size of the franchise) on conflict, while at the same time attempting to overcome the identification problem. In 1853, Colombia established universal male suffrage. Using a simple difference-indifferences specification at the municipal level, we find that municipalities where more voters were enfranchised relative to their population experienced fewer violent political battles while the reform was in effect. The results are robust to including a number of additional controls. Moreover, we investigate the potential mechanisms driving the results. In particular, we look at which components of the proportion of new voters in 1853 explain the results, and we examine if results are stronger in places with more political competition and state capacity. We interpret our findings as suggesting that violence in nineteenth-century Colombia was a technology for political elites to compete for the rents from power, and that democracy constituted an alternative way to compete which substituted violence.
\end{abstract}

Keywords: Democracy, Civil Conflict, Colombia.

JEL: D72, D74, P16.

\footnotetext{
*We thank Malcom Deas, David Laitin, Jorge Orlando Melo, Fernán González, James Robinson and seminar participants at Universidad del Rosario, "New Perspectives on Violence in Colombia" (Universidad de los Andes and David Rockefeller Center for Latin American Studies Center), the Latin American Studies Association 2012 Annual Meeting, and the World Economic History Conference 2012.

$\dagger$ Universidad de los Andes, Department of Economics, Cra $1 \mathrm{~N}^{\circ} 18 \mathrm{~A}$ - 12 Bogotá, Colombia. E-mail: lfergusson@uniandes.edu.co

†Universidad del Rosario, Department of Economics, Cl 14 N 4 - 80 Bogotá Colombia. E-mail: juan.vargas@urosario.edu.co
} 


\section{Introduction}

This paper studies the effect of strengthening democracy, as captured by an increase in voting rights, on violent civil conflict. The relationship between democracy and conflict (or peace) is at the center of many theories of democracy, democratization, and conflict. One line of research suggests that democratization is a way to avert conflict. In the theory put forward by Acemoglu and Robinson (2006), for example, politically excluded groups in society exercise violence (de facto power) to obtain policy concessions, unless they are given some de jure or "institutional" power. Democratization constitutes a credible concession of such power, and therefore it avoids conflict. Another possibility is that democracy is a substitute for violence, not because it offers institutional power to the excluded majority, but because it constitutes a technology to allocate power between political elites. This technology replaces the use of force.

Focusing on inter-state conflicts, the long-standing democratic peace hypothesis states that democracies are unlikely to go to war with each other. Among the arguments that have been used to support this idea is the fact that democracies face institutional constraints: in a democracy, the rulers are accountable to the population and the population at large wants to avoid the calamities of war, like the cost of conscription. Another argument is that democracies develop a set of "democratic norms" that preclude war from taking place. These types of arguments can be (and have been) also applied to intrastate conflicts, and there is some empirical evidence pointing to a statistical association between indicators of democracy or political freedom and measures of internal violence (e.g. state repression, terrorism or human rights abuses) $)^{1}$.

But democracy may also exacerbate conflict. This may happen through several channels. For example democracy (or at least democratic elections) fuel political (as well as other) identities and this breeds violence. Eifert, Miguel, and Posner (2010) provide evidence consistent with this mechanism. The authors find that ethnic identities in Africa are strengthened by exposure to political competition: the closer a competitive presidential election is, the more likely are survey respondents to identify themselves in ethnic terms. More generally, by creating winners and losers (in elections), democracy may increase incentives for violent behaviors that could otherwise be avoided via, say, powersharing agreements. A key question is what are the conditions under which losers will peacefully relinquish power (Chacón, Robinson, \& Torvik, 2011). If these conditions are not met, then 'more democracy' may well imply more violence.

Whatever the theoretical relationship between democracy and conflict, studying the empirical relationship between these two variables presents an enormous challenge. On

\footnotetext{
${ }^{1}$ For instance, Abadie (2004) finds that political freedom explains terrorism, but it does so in a nonmonotonic way, with countries in some intermediate range of political freedom being most prone to experiencing terrorism. Davenport (1997) finds that elections reduce the use of censorship and political restrictions, as well as human rights violations (see also Davenport (2007)).
} 
the one hand, there are a number of conceptual problems in defining and measuring democracy. On the other hand, for any measure of democracy, this variable is likely to be jointly determined with violent conflict and hence one has to be very cautious in interpreting any empirical association between the two variables as causal.

We take advantage of an experiment of history to examine the impact of one simple, measurable dimension of democracy (the size of the franchise) on conflict, while at the same time attempting to overcome the identification problem. We focus on nineteenthcentury Colombia. In 1853 Colombia enacted a Constitution that abolished slavery as well as literacy and wealth requirements for voting, effectively establishing universal male suffrage. The Constitution also introduced, for the first time, direct presidential elections.

This natural experiment provides us with an ideal framework for studying the impact of extending voting rights on levels of civil conflict. First, the increase in voting rights was very significant since the preexisting wealth and literacy requirements together with the existence of slavery disenfranchised the majority of the population. Second, like many other Latin American countries in the XIXth century, during the early decades after independence from colonial powers Colombia faced a number of civil wars and politically motivated violence. Crucially for the analysis, and as explained in the data section, we have a good municipal-level measure of whether a battle was fought in any given year. Finally, and also key for our empirical strategy, in 1851 Colombia had one of its first comprehensive population censuses. The census data allow us to build a proxy for the number of enfranchised "new voters" in each municipality, following the national-level reform of 1853. Indeed, given preexisting differences in their demographic composition, some municipalities experienced a larger increase in their voting population than others, providing an ideal experiment to assess whether such places experienced more or less conflict following the reform.

Our basic strategy and main results are illustrated in Figure 1. The figure divides municipalities between those with a high proportion of new voters (where our proxy for new voters as percent of total population in 1853 is above the median) and those with a low proportion of new voters (which are below the median). We next compute, for each group and each year, the average number of battles that were fought every year in a given municipality. The circles in the figure represent this number for the municipalities with a high proportion of new voters. The triangles, on the other hand, are the corresponding averages for municipalities with a low proportion of new voters. Finally, the smoothed lines correspond to a locally weighted regression of the average number of battles on years (the solid line is the one for the high-voters municipalities, and the dashed line the one for the low-voters one). Vertical lines are shown for the year 1853 (dashed, when the Constitution extending the franchise was enacted) and for 1856 (solid, when the first presidential election with universal male suffrage and direct voting took place).

A number of messages emerge from Figure 1. First, prior to 1853, the municipalities 
with a high proportion of new voters do not differ, in terms of the incidence of battles, to those with a low proportion of new voters. This validates our identification assumption that the preexisting differences in demographic structures are not correlated with differential trends in violence. Second, starting around 1853, both groups of municipalities begin to diverge. In particular, in line with the idea that more democracy (here, voting rights for a larger share of the population) is a factor contributing to a fall in conflict, we observe that the incidence of battles in the low-voters municipalities is higher than in high-voters municipalities. Third, the difference seems to be maximized just after 1856 , when the presidential elections under the new rule took place. Also interestingly, the gap between the two types of municipalities starts to close in 1863. This is a meaningful year, as Colombia adopted a new (ultra-federal) constitution with individual states changing voting rights. Most of them pulled part of the extension of voting rights that the previous (1853) Constitution had enacted. In short, Figure 1 shows that, while in effect, the extension of voting rights of the 1853 Constitution decreased violence in places that benefitted more with this extension relative to places that benefitted less.

In the rest of the paper, we verify that the message from Figure 1 survives statistical scrutiny and is robust to a number of specification checks. We run a simple difference-indifferences specification that tests our hypothesis. In particular, we estimate a municipallevel regression where the dependent variable is the number of battles fought each year and the main independent variables are our proxy for new voters, an indicator variable that equals one while the 1853 Constitution was in effect, and the interaction term between these two. We find that the coefficient of the latter is negative and significant, implying that a one standard deviation increase in the proportion of new voters reduces the incidence of violence in 0.6 percentage points after the 1856 presidential elections.

The results are robust to including a number of additional controls that proxy for differential pre-trends in violence, a full set of year and municipality fixed effects and differential trends parametrized as functions of observable municipality characteristics. The observable characteristics include geographic controls (historical road density, river density, and altitude), a measure of the partisanship leaning of each municipality (whether Ospina, the conservative candidate, had the majority of votes in the 1856 presidential elections), and historical institutional controls (an index of colonial institutions and the number of colonial functionaries, as compiled by García-Jimeno (2005) from Durán y Díaz (1794)).

In addition, both to test for the presence of potential differential pre-trends between municipalities with high and low proportion of new voters before the 1853 reform, and to deal with the fact that Colombia experienced a number of Constitutional reforms (many of which affected voting rights) we verify the validity of the results to the inclusion of differential trends following other major changes in voting rights prior to the 1853 Constitution. Specifically, we include time dummies and their interaction with our measure 
of new voters for the periods under which the 1832 and the 1843 Constitutions were in place. In line with the evidence from Figure 1, we find no evidence of differential trends in violence for municipalities with different shares of new voters prior to the 1853 reform.

We also take into account that further constitutional changes in 1863 reversed in most municipalities the suffrage extensions granted by the 1853 Constitution, while deepened them in a few. Indeed, under the 1863 federal Rionegro Constitution, each state adopted its own suffrage rules. We take advantage of this to examine whether municipalities in states that further increased voting rights experienced a further decrease in violence after 1863 while municipalities in states that reintroduced suffrage restrictions observed more violence. We find a a differential increase in the incidence of battles in places that witnessed a reduction of voting rights after 1863. This is additional suggestive evidence in line with the idea that limiting voting rights created violence. However, we are more cautious about interpreting this correlation as causal, as the decision to extend or limit the suffrage requirements in each state is clearly endogenous and could be related with expected levels of violence. This contrasts our main result using the 1853 reform, in which we take advantage of a national-level reform and exploit the extent to which it differentially affected municipalities.

While our exercises directly test the validity of our identification assumption by ruling out differential trends in violence, one may still be concerned that the population structure, which largely determines which places had high and low proportion of new voters, is really a consequence of historical patterns of violence that affected the sex and age distribution of local populations. To rule this out, we run our set of regressions computing the share of new voters using the population structure that was present at the time of the 1843 census (the last one before 1851). With this specification, we test whether the effect of new voters simply reflects violence-induced population recompositions leading up to the 1853 reform.

Our main result is robust to all these specification tests, providing convincing evidence of the pacifying effect of franchise extension in Colombia. To investigate what forces plausibly drive these results, we perform a number of additional exercises. First, we look at which components of the proportion of new voters in 1853 explain the results. We find that most of the effect is accounted for by married men regardless of their age. Instead, neither slaves nor unmarried youngsters or old men explain the effect of new voters on violence. Married men are a large proportion of the population in most municipalities, so this finding is perhaps not surprising.

The fact that the proportion of slaves plays a small role is both reassuring about the validity of the identification assumption and falls in line with Colombian historiography on the causes of the nineteenth-century civil wars. It is reassuring because places with many slaves tended to be very different to places with few slaves. If all the effect was coming from the comparison between these two types of places, we would be worried 
that other omitted variable connected with the slave economy could explain the observed differences in violence patterns. It falls in line with the historical record, too, as the civil wars of the nineteenth century have mostly been depicted as fights between political elites, not as evolving around emancipation or other economic vindications by excluded slaves (Palacios \& Safford, 2002, Chapter 9). Also, that the proportion of married free men (regardless of age) is what drives the results is in line with the idea that this segment of the population plausibly includes the people who were most politically active at the time.

Finally, that youngsters do not drive the results is also reassuring of the identification assumption. In particular, a natural hypothesis is that violence is driven, or at least partially correlated, with the share of young men in the population, if only because young men are the main fighters of partisan armies. Moreover, as Figure 1 shows, the 1853 Constitution period was one of escalating violence. Hence, if our results were mainly driven by young men, a potential concern is that we are just picking up a differential behavior between municipalities with different availability of fighters in a period of escalating national violence, for reasons unrelated with the changes in the electoral rules.

The previous observation about increasing violence during the 1853 Constitution era is also important to give a precise interpretation to our results. We find that municipalities where more voters were enfranchised relative to their population experienced a lower incidence of violent battles relative to the rest of the country during the 1853 Constitution era. The interpretation is subtle: given there are elections, we find that there is less violence if more people can participate in them. However, compared to other years, the overall level of violence during the 1853 Constitution period was unusually high. This increase could well have been fueled partly by the 1853 Constitution itself. However, we are not able to separate the effect of the constitution from the myriad of other changes in circumstances that could have occurred at this time in Colombia 2 . In other words, we cannot give a causal interpretation to the estimated direct impact of the 1853 Constitution on violence. Instead, and as we will show in detail below, we are confident that our interaction coefficient only captures differences between municipalities that stem from their varying degrees of new potential voters and not from other confounders. Hence our conditional statement, which does not rule out that elections may exacerbate violence. We cannot directly test this possibility with our empirical strategy, but we can say that elections with more participation reduce violence.

To understand the potential mechanisms that cause this decline, we offer a few additional results. In particular, we look at whether results differ depending on two key municipal characteristics: the degree of political competition and the extent of state ca-

\footnotetext{
${ }^{2}$ In fact, following major institutional reforms, violence was not uncommon in the history of Colombia, the most noteworthy example being the War of a Thousand Days that followed the establishment of the 1866 Constitution, which ruled the country for most of the XXth Century.
} 
pacity. We find that the impact of new voters is stronger in places with stronger state institutions and with more political competition. We interpret both of these results as suggesting that violence in nineteenth-century Colombia was essentially a technology for political elites to compete for the rents from power. Elections with a larger franchise could undermine and substitute this technology, reducing violence.

We next describe the data and sources in section 2. Section 3 explains our identification strategy and section 4 reviews our empirical findings including all the robustness checks and the examination of potential mechanisms. Finally, section 5 concludes.

\section{Data}

The main variables in our analysis are the incidence of violence and the proportion of new voters at the municipality level. The proportion of new voters in each municipality comes from the 1851 Colombian census. The census categories do not exactly match the categories of enfranchised population, but they are sufficiently close to give us the variation necessary for our empirical strategy. In particular, the 1853 Constitution gave voting rights to all male citizens over the age of 21, including former slaves (now free men). Married men under the age of 21 could also vote. Hence, using the 1851 census, we can approximate the voting population in each municipality as the sum of the number of single males over 16 (who would be old enough to vote by the time of the 1856 elections), the number of married slaves, and the number of married free men.

Therefore, the only category of voters that we cannot count is the number of single slaves over the age of 21. However, there are various reasons for which this is not a major concern. First, while we do not know the age composition of slaves, a very large percentage $(50 \%)$ of free men were under age. If the age composition of slaves resembled to some extent that of free men, then many of the single slaves were unable to vote in 1856. Second, the census figures indicate that $40 \%$ of slaves were married, a sizable proportion which is included in our proxy. Third, just $0.7 \%$ of Colombians were slaves in 1851 (Tovar, 2007). Of course, this hides some important regional variation, but on average excluding single slaves implies excluding a very small share of potential voters (just $0.007 * 0.60$ even assuming they all met the age requirement). Finally, under the Ley de Vientres already in place in 1851, offsprings of slaves were free once they reached 18 years of age, so most of those classified as single slaves in the 1851 census are likely to be too young to vote by 1856 .

Undoubtedly, in nineteenth-century Colombia, a national-level census was a challenging task given the limited capacity of the state. Gómez (1969) mentions some of the hurdles: widowers were often classified as single, it is uncertain how unmarried couples were classified, some isolated communities (especially indigenous) were not counted, some people feared that the census would imply forthcoming taxation and tried to avoid it, and 
the quality of the data varied by regions. In spite of all these difficulties, he concludes that "the 1851 census (...) was the one with less problems [out of all nineteenth-century censuses]" (p. 91).

Moving to our second key variable, we rely on Riascos Grueso (1950) to count the number of battles in each municipality and year in Colombia during the nineteenth century. In his Geografía Guerrera de Colombia (War Geography of Colombia), Riascos Grueso recorded, municipality by municipality, the history of battles taking place in each location since independence in 1819 and into the War of a Thousand Days at the eve of the century. It is important to note that these battles include national-level civil wars as well as armed local disputes between political factions.

To illustrate the coding of these data, consider the following two examples of entries in Riascos Grueso's database. Under the entry for Puerto Colombia municipality (in the northern state of Atlántico) it reads:

The troops of Luis Bryón, Rafael Tono, Jerónimo Carbono, Pedro Celestino Guillén y Gutierrez and Juan Illingrot, won in the years (..) 20 and 21. Under Urdaneta's dictatorship, his side combatted with the rebels, led, in turn, by generals Policarpo Martinez and Ignacio Luque. In the year 40, rebels and government forces again fought, as part of the revolution that exploded in the atlantic coast in October that year ${ }^{3}$.

Taking into account that Urdaneta's dictatorship took place in 1830, our entry for the number of battles in Puerto Colombia equals one in 1820, 1821, 1830, and 1840, and zero otherwise. Notice that all battles in this municipality took place before 1853 . The next example shows the case of a municipality, Rionegro (in the state of Antioquia) with most battles occurring after 1853:

On September 7 of 51 regular forces met in combat with the rebels, led by generals Tomás Herrera and Eusebio Borrero, defeated. Nine years later, centralists and federalists faced each other. In the year 64, January 4, doctor Pedro Justo Berrío defeated the militias of doctor Pascual Bravo, president of the state of Antioquia, who died in fighting (...) action which (...) permitted the victorious chief to take over Medellín and assume power of the antiqueño state. In the year 85 general Cándido Tolosa fought, twice, the government forces of captain Alejandro Ardila, who repelled the attacks. ${ }^{4}$

\footnotetext{
${ }^{3}$ The translation is our own. The original entry reads: "Triunfaron la tropas de Luis Bryón, Rafael Tono, Jerónimo Carbono, Pedro Celestino Guillén y Gutierrez y Juan Illingrot, en los años (...) 20 y 21. Cuando la dictadura de Urdaneta, combatieron los defensores de éste con los rebeldes, dirigidos, en su orden, por los generales Policarpo Martinez e Ignacio Luque. El año 40, se batieron nuevamente insurgentes y gobiernistas, como consecuencia de la revolución que estalló en la costa atlántica en octubre de dicho año."

4 "El 7 de septiembre del 51 combatieron las fuerzas regulares con las insurgentes, dirigidas por los
} 
Rionegro thus exhibits one battle in 1851, 1860, and 1864, two battles in 1885, and zero in the remaining years. We use the number of battles in each municipality and year as our dependent variable. However, our results are almost identical when relying on a dummy variable that equals one if the municipality experienced positive battles in a given year and zero otherwise.

We also constructed a set of additional historical controls for robustness checks and to explore the mechanisms that may explain our results. Theses variables and their sources are listed in Appendix Table A-1. From the 1851 census, we use some of the components of our "proportion of new voters" variable to explore which of them are most important for the differences in violence between municipalities. Specifically, we compute the shares of young single males (ages 16-50), old single males (ages 50 and over), married free men, and married slaves.

To construct a measure of political competition at the municipality level we rely on Bushnell (1970), who presents municipal-level data on the 1856 presidential elections. Our measure of political competition equals zero when, among the top two candidates, the winning candidate in municipality $m$ received all votes, and equals one if votes were equally split among the top two contestants. That is, we measure political competition as

$$
1-(\text { votes first }- \text { votes second }) /(\text { votes first }+ \text { votes second }) \text {, }
$$

where votes first is the number of votes obtained by the top candidate in municipality $m$ and votes second are the votes obtained by the runner-up. To control for average partisanship in each location, we include an indicator of whether Ospina, the conservative candidate who was ultimately elected president in the 1856 elections, had the majority of votes in such elections.

To examine mechanisms, we rely on two simple measures of state capacity at the municipality level. First, using municipal foundation dates from Bernard and Zambrano (1993) we compute the age of each municipality in our sample. The idea is that older municipalities have on average stronger state institutions than newer ones. Second, we measure the strength of colonial institutions in each municipality with the index proposed by García-Jimeno (2005). With information from Durán y Díaz (1794), García-Jimeno (2005) builds an index of state capacity, ranging from 0 to 4 , which counts whether a municipality had a tobacco estanco, aguardiente estanco, mail service and alcabala during the Spanish colony (estancos were state monopolies and alcabalas consumption taxes).

Also, in 1863 under the federal Rionegro Constitution, each of the states adopted its

generales Tomás Herera y Eusebio Borrero, vencido. Nueve años después, lidiaron centralistas y federalistas. El año 64, enero 4, triunfó el doctor Pedro Justo Berrío sobre las milicias del doctor Pascual Bravo, presidente del estado de Antioquia, quien pereció en la refriega (...), acción ésta (...), cuya victoria permitió al jefe vencedor tomar a Medellín y asumir el mando del estado antioqueño. El año 85 combatió el general Cándido Tolosa, dos veces, las fuerzas gobiernistas del capitán Alejandro Ardila, quien rechazó los ataques de aquél." 
own decision regarding suffrag 5 . We take advantage of this to code an additional pair of dummy variables which specify whether voting rights increased or decreased in 1863 . Since several states took steps in both directions at the same time (for example, Santander and Cundinamarca reduced the age to 18 , but reinstated the literacy requirement) we followed a conservative approach and only assigned a value of one to municipalities in states where voting rights unambiguously increased or decreased. The only state with unambiguous increase in voting rights is Magdalena, with a decrease in voting age to 18 years and no return to other restrictions, while the states with unambiguous decrease in voting rights are Tolima, incorporating either literacy or wealth requirements, and Boyacá, incorporating literacy. Other states, like Antioquia, Bolívar, and Cauca, simply continued granting voting rights to males over the age of 21 and married men regardless of age. Finally, our regressions include a number of additional controls, notably municipal geographic conditions (historical road density, river density, altitude).

Table 1 presents summary statistics for the variables in our analysis. On average, new voters constituted close to $25.3 \%$ of the population, yet this figure ranged between $15 \%$ and $53 \%$. During the whole estimation period, from 1821 to 1885 , there were on average 0.02 battles in each municipality and year. However, the variance of this variable is large, with a standard deviation of 0.14 and municipalities with as many as 4 battles in a given year. Table 1 also shows the incidence of battles for municipalities with a high and low proportion of new voters (which correspond respectively to the observations below and above the mean of this variable). Interestingly, the average incidence of battles is the same for these two groups of municipalities throughout the entire century. However, once we look at the the 1857-1862 period, relevant for the 1853 Constitution, we observe that the level of violence is somewhat higher in the subsample of municipalities with a lower proportion of new voters. This difference is suggestive of the pacifying effect of franchise extension, which we carefully explore below with our regression analysis. The descriptive statistics of the (time-invariant) controls are also reported at the bottom of Table 1.

\section{Empirical Strategy}

Our empirical strategy exploits the introduction of universal male suffrage in Colombia's 1853 Constitution. We take advantage of the fact that this extension of the franchise

\footnotetext{
${ }^{5}$ Suffrage rights in 1863 were set as follows: (i) Antioquia: men with at least 21 years of age, and married men regardless of age; (ii) Bolívar: men with at least 21 years of age, married men, and emancipated slaves; (iii) Casanare (Boyacá): literate men with 21 years of age or older; (iv) Cauca: men with at least 21 years of age, and married men regardless of age; (v) Cundinamarca: literate men with 18 years of age or older; (vi) Magdalena: men with at least 18 years of age, and married men regardless of age; (vii) Santander: literate men with 18 years of age or older; (viii) Tolima: men with at least 21 years of age, and married men regardless of age, that either are literate or have wealth exceeding 200 pesos. We do not include Panamá, also a state of Colombia at the time, because we have no information on violence for its territory.
} 
affected some municipalities more than others because of their preexisting demographic structure. Our most basic specification is a simple difference-in-difference regression for municipality $m$ at time $t$ :

$$
\begin{aligned}
\text { battles }_{m, t}=\beta_{1}+\beta_{2} & \text { (new.voter } \left.s_{m} \times d_{1853 \text { Constitution }}\right) \\
& +\beta_{3} \text { new.voter } s_{m}+\beta_{4} d_{1853 \text { Constitution }}+\varepsilon_{m, t} .
\end{aligned}
$$

where battles $_{m, t}$ is the number of battles in municipality $m$ in year $t .^{6}$ The key proxy of the extent to which the introduction of universal male suffrage affected municipality $m$ is new.voter $s_{m}$. As explained in the preceding section, this proxy is built using the 1851 census. The main coefficient of interest, $\beta_{2}$, is the interaction of new.voter $s_{m}$ with $d_{1853 \text { Constitution }}$, a dummy variable that equals 1 for the time interval under which the 1853 franchise extension was in place in the entire country. In all specifications, we cluster standard errors at the municipality level, as there may be important correlation in the level of violence within a given municipality across time.

If $\beta_{2}<0$, then municipalities where the 1853 Constitution enfranchised more voters relative to their population experienced less violent battles while the the reform was in effect than those where the share of enfranchised population was smaller. A negative value of $\beta_{2}$ therefore indicates that the extension of voting rights causes less violence, while a positive coefficient would suggest that it exacerbates violence.

To verify the robustness of our results, we also run the following more demanding specification:

$$
\begin{aligned}
& \text { battle } \left._{m, t}=\beta_{1}+\beta_{2} \text { (new.voter } s_{m} \times d_{1853 \text { Constitution }}\right)+ \\
& \sum_{x \in \mathcal{X}} \beta_{x} x_{m} d_{1853 \text { Constitution }}+\delta_{m}+\delta_{t}+\varepsilon_{m, t},
\end{aligned}
$$

In particular, to control for national-level trends in violence, in (2) we include a full set of year fixed effects, $\delta_{t}$. While during the XIXth Century several battles were regional, a number of national-level confrontations also took place. The year fixed effects flexibly control for all these national trends, or any other year-specific characteristics which influence the overall level of violence. Similarly, we include municipality fixed $\delta_{m}$ effects that flexibly control for any fixed characteristics that may influence the average level of violence in municipality $m$.

Equation (2) also includes the interaction of observable municipality characteristics $x_{m}$ (each one in our set of control variables) with $d_{1853}$ Constitution. Hence, this regression allows for differential trends for municipalities with different characteristics $x_{m}$. If these

\footnotetext{
${ }^{6}$ Results are very similar if, instead of using the number of battles as the dependent variable we rely on a dummy variable that equals one if there is any positive number of battles in municipality $m$ at time $t$ and zero otherwise.
} 
characteristics, rather than the presence of more new voters, explain the different violence behavior of municipalities, then $\beta_{2}$ should no longer be significant. Instead, if $\beta_{2}$ retains statistical significance, this is reassuring about the validity of our identification assumptions.

To make sure that the changes in violence across regions after the franchise extension are not driven by other factors that also happen to be correlated with the size of new.voters, we perform additional robustness checks. On the one hand, with the inclusion of an interaction of the number of new voters with other meaningful institutional periods preceding the 1853 Constitution, we verify the assumption that municipalities with high and low number of new voters have "parallel trends". In particular, we test whether there were any differential trends during previous regimes in the rules of the game regarding the size of the franchise (specifically, those established by the 1832 and the 1843 Constitutions). On the other hand, while this type of exercise tests the validity of our identification assumption by ruling out differential trends in violence, one may still be concerned that the population structure, which largely determines which places had high and low proportion of new voters, is really a consequence of historical patterns of violence that affected the sex and age distribution of local populations. To rule this out, we run our set of regressions computing new.voters using the population structure that was present at the time of the 1843 census (the last one before 1851). We find similar results, suggesting that our estimated share of new voters does not simply reflect violence-induced population recompositions leading up to the 1853 reform.

In our estimation, we focus on the period 1821-1885. While Colombia (then New Granada) first declared its independence in 1810, it seems reasonable to exclude the years of conflict with the Spaniards to consolidate the independence. By 1821, with the Cúcuta Constitution, independence had been consolidated. In 1886, on the other hand, a new Constitution was put in place. This Constitution, that was marked by an effort to centralize the state authority, inaugurated a new period in Colombia's history. It survived the 3-year long War of the Thousands Day (1899-1902) and was in place for over a century after it was replaced by the current 1991 Constitution.

\section{Results}

\subsection{Baseline results}

Table 2 presents our basic difference-in-differences estimates of the effect of the 1853 democratization on political conflict in Colombia. We estimate model (1) by OLS.7 The

\footnotetext{
${ }^{7}$ We focus on the OLS estimates since linear models provide the best estimate of the true conditional expectation function. In contrast, non-linear models are very sensible to model specifications and suffer from the incidental parameters problem in the presence of fixed effects (Angrist \& Pischke, 2009).
} 
key message from this table is that our main coefficient of interest, the interaction of the municipal-level proportion of new voters with the dummy that captures the period in which the reform was in place (i.e. before the adoption of the federal Rionegro Constitution in 1863) is negative and significant across specifications.

While the franchise was extended in the second half of 1853, the first elections under the new regime took place three years later, in 1856. In columns 1 and 2 of Table 2, we thus run regressions in which the time dummy equals 1 for the period 1854-1862, and for the period 1857-1862, respectively. It is clear that the effect is present only once the reform was effective, after the 1856 elections. We thus focus on the post 1856 period hereafter.

The negative coefficient of the interaction between the estimated proportion of new voters and the dummy that captures the period in which the reform was active in column 2, should be interpreted as suggesting that municipalities where more voters were enfranchised relative to their population experienced a lower incidence of violent battles relative to the rest of the country. The interpretation is subtle: given there are elections, we find that there is less violence if more people can participate in them. Indeed, notice that the coefficient associated with the 1857-1862 dummy is positive and significant, suggesting that there is more violence overall during this period. This increase could well have been fueled partly by the 1853 Constitution itself. However, we are not able to separate the effect of the constitution from the myriad of other changes in circumstances that could have occurred at this time in Colombia. Instead, and as we will show in detail below, we are confident that our interaction coefficient only captures differences between municipalities that stem from their varying degrees of new potential voters and not from other confounders. Hence our conditional statement, which does not rule out that elections may exacerbate violence. We cannot directly test this possibility with our empirical strategy, but we can say that elections with more participation reduce violence.

To gauge the size of this effect recall that

$$
\beta_{2}=\left[\frac{\text { dbattles }_{m, t}}{\text { dnew.voter } s_{m}}\right]\left(d_{1853 \text { Constitution }}=1\right)-\left[\frac{\text { dbattles }_{m, t}}{\text { dnew.voter } s_{m}}\right]\left(d_{1853 \text { Constitution }}=0\right) .
$$

Given our estimate of $\beta_{2}$, this means that having 4.17 percentage points more new voters than the average municipality (a one-standard deviation increase, see Table 1), means experiencing about 0.7 percentage points $(-0.0016 \times 4.17)$ less battles during the period 1857-1862 (from an average incidence of 0.04 over such period, Table 1).

In column 3 (and in all remaining specifications) we include a full set municipality and year fixed effects. These control for any municipality-specific time-invariant heterogeneity as well as for any aggregate shock that affects all the municipalities at any moment of time. By including the municipality and year fixed effects we cannot report the coefficients 
on the time dummy and the share of new voters. The interaction of interest does not change in magnitude or significance as we include the two-way fixed effects.

Further, in column 4, we allow for differential trends parametrized as functions of the set of (time-invariant) observable municipal characteristics, as described in section 2 , and illustrated in equation (2). Our main result is robust to including such additional covariates, and the magnitude of the estimated interaction of interest drops only slightly $]^{8}$ This is reassuring for our identification strategy.

\subsection{Robustness}

Though by granting universal male suffrage the 1853 Constitution was the most radical in terms of franchise extension, it was not the only major institutional reform during the nineteenth century in Colombia..$^{9}$ After the first Constitution of independent Colombia (1821), other constitutions were declared before the 1853 Charter (1832 and 1843). These constitutions made small changes in the franchise in one direction or the other, but there are some common aspects. For instance, indirect presidential elections were the rule in the XIX century (with the exception of the inter-constitutional period between 1853 and 1863), and the franchise was typically restricted to literate males over 21 (underaged could vote only if they were married), often with additional income or wealth requirements. After 1853, the 1863 Constitution consolidated a federal system and allowed each province to write their own Charter with different franchise rules ${ }^{10}$ Most states responded reversing universal male suffrage.

These institutional changes could have had an effect on the incidence of battles. With the inclusion of year fixed effects we are already taking into account any overall changes in violence associated with these different periods. This type of overall trends cannot, therefore, be contaminating our results. For these other constitutional reforms to affect our main results, it would have to be the case that they differentially affected places with different proportions of the new voters as enfranchised by the 1853 Constitution. While this is a more intricate and perhaps less plausible story, we can directly test it. We do so on Table 3 ,

As a benchmark, column 1 repeats the regression in column 4 of Table 2 , that includes year and municipality fixed effects as well as differential trends. Similar regressions are ran in columns 2 and 3 of Table 3 but, instead of a 1856-1862 dummy capturing the

\footnotetext{
${ }^{8}$ In this case the estimated coefficient suggest that one additional standard deviation in the proportion of new voters $(4.17)$ translates into $0.6(-0.00147 \times 4.17)$ percentage points less incidence of battles after the presidential elections and during the period where the franchise extension was in place (1857-1862).

${ }^{9}$ As we noted, the 1853 Constitution implemented direct elections and abolished both literacy and property and rents requirements. It also abolished slavery. All male over 21 could vote and even younger men could do so as long as they were married.

${ }^{10}$ The country's name changed then from Confederación Granadina to Estados Unidos de Colombia (United States of Colombia).
} 
duration of the franchise extension, we interact new.voters with period dummies for each one of the main time intervals under which the previous constitutions prevailed. Hence, in column 2 we interact our measure of new voters with a dummy that equals one for the years 1833-1842 and zero otherwise. This period, corresponding to the Nueva Granada (1832) Constitution, had indirect elections with franchise restricted to males over 21 (or else be married) and literacy and possession of rents or assets. In column 3, in turn, a dummy that equals one for the period 1844-1855 captures the period ruled by the 1843 Constitution. This is also a time with indirect elections and suffrage restrictions based on literacy and possession of rents or assets, but where the voting age was 21 years regardless of marriage status.

Overall, the message from columns 1 to 3 is that the negative coefficient in our baseline specification does not capture other more general negative differential pre-trends between municipalities with high versus low proportion of new voters. Indeed, the interaction of new.voters with these other time periods is not significant. Moreover, in these cases the interaction term is positive and very small. In particular, it bolsters our main result that in the period immediately preceding the 1856 elections (see column 3) the interaction coefficient is not significant and very small in magnitude. Thus, it seems there are no prior differential trends and only during the prevalence of universal male suffrage did the abundance of new voters help reduce violence. This confirms our identification assumption that municipalities with a high proportion of new voters would not have had different levels of violence than those with few new voters, had it not been for the introduction of universal male suffrage in 1853. This is perhaps most clear in column 4, where we include each of the time intervals of columns 1-3 and their interactions with the proportion new voters. Only the interaction with the 1857-1862 dummy retains statistical significance.

In short, the evidence that extending voting rights served to reduce violence is very robust to controlling for potential omitted variables or differential trends.

Recall that a new Constitution in 1863 allowed each state to chose the extent of their own franchise, resulting in most states backlashing relative to the 1853 reform and reducing the size of the franchise, and one (Magdalena) extending it ${ }^{11}$ This constitutes an interesting set up to test the validity of our results. Since each of the states adopted its own decision regarding suffrage, we can examine whether municipalities in states that further increased voting rights had less violence while states that reintroduced suffrage restrictions observed more violence. We investigate this hypothesis in the final column of Table 3 by adding two additional variables: 'Post 1863 increase', which equals one after 1863 and for municipalities in states were voting rights unambiguously increased

\footnotetext{
${ }^{11}$ It is important to note that, in 1858, the Confederación Granadina Constitution was adopted. Yet, it did not change universal male suffrage, and so we consider its period as a continuation of the 1853 innovation of the franchise.
} 
further in 1863 (Magdalena); and 'Post 1863 decrease', which equals one after 1863 and for municipalities in states were voting rights unambiguously decreased further in 1863 (Tolima and Boyacá). We show that, while our interaction of interest is still negative and significant, the coefficient on 'Post 1863 decrease' is positive and significant. This suggests that the incidence of battles increased after the 1863 reform in municipalities of states that reduced voting rights. This is additional suggestive evidence in line with the idea that limiting voting rights created violence. The coefficient on 'Post 1863 increase' is negative, also in line with this idea, but it is not statistically significant at conventional levels. While suggestive and in line with our main result, we are more cautious about interpreting these correlations as causal, as the decision to extend or limit the suffrage requirements in each state is endogenous and could be related with expected levels of violence.

In short, Table 3 provides very reassuring evidence of the validity of our identification assumption by ruling out differential trends in violence before the 1853 reform for places with high and low proportion of new voters. However, one may still be concerned that the population structure, which largely determines which places had high and low proportion of new voters, is really a consequence of historical patterns of violence that affected the sex and age distribution of local populations. While Table 3 implies this is unlikely, as an additional robustness test, we run a set of regressions equivalent to those summarized in Table 2 but computing new.voters using the population structure that was present at the time of the 1843 census (the last one before 1851).

Table 4 reports the results. The interaction of interest is negative and significant across columns. ${ }^{12}$ Interestingly, this is true even in column 1 , where we define $d_{1853 \text { Constitution }}$ as a dummy variable that equals 1 from 1854 to 1863. Unlike our regression using the share of new voters from the 1851 census (Table 2), this suggests that the 1853 reform had an effect on violence even prior to the first elections under universal male suffrage in 1856 . The estimated coefficients are about three times larger than those from Table 2, and their significance level is higher. Using the point estimate of the interaction from column 4, a one standard deviation increase in the proportion of the 1843-based new voters translates into $1.5(-0.00434 \times 3.37)$ percentage points less battles during the period 1857-1862.

Before examining the mechanisms that might explain our results, we offer a final robustness test. One objection that could be raised against our results is that battles may not have been fought in the same places where political tensions occurred. That is, while the cause of violent conflict could have been centered at a particular municipality, the battle itself could have occurred in a neighboring municipality, where factions of the parties met in the battleground. Perhaps such places had certain characteristics that

\footnotetext{
${ }^{12}$ Columns 1 to 4 have the same structure as Table 2, while column 5 adds our 'Post 1863 increase' and 'Post 1863 decrease' dummies to test for impacts of further changes in voting rights with the 1863 Constitution
} 
made them ideal for violent confrontation, for geographic or demographic reasons. Aside from the fact that we control for geographic characteristics and our observation that the most obvious demographic advantage for battles (abundance of young men) is not driving the results, there are two additional answers to this potential objection.

First, our reading of Riascos Grueso's War Geography suggests that this was not the case systematically. There are many accounts of battles that occurred in municipalities where the fighting factions of the parties were located.

Second, we can perform an additional empirical exercise to gauge the relevance of this objection. In particular, in Table 5 we run regressions at the canton level, hence considering much larger geographical areas ${ }^{13}$, The regression tests whether cantons with a larger share of new voters experienced more battles than cantons with smaller shares of new voters. In column 1, we run the basic regression with a full set of year and canton fixed effects and no additional controls. Again, we find that the interaction coefficient is negative and significant. The same is true in column 2, where we include our full set of controls, now measured at the canton level, interacted with the dummy variable for the 1857-1862 period. In this case the estimated coefficient is even more statistically significant and virtually unchanged in magnitude. Hence, even controlling for differential trends parametrized as functions of observable characteristics, cantons with a higher proportion of voters had less battles than those with less new voters during the relevant period. Since this finding relies on much larger geographical units than municipalities, it assuages concerns arising from fighting taking place in a given municipality but truly caused by the incentives in a neighboring area.

The size of the coefficients in this new regressions is also informative. Given our estimate of the interaction, having 3.37 percentage points additional new voters than the average canton (a one-standard deviation increase in the canton-level dataset), translates into 2.2 percentage points $(-0.00647 \times 3.37)$ less battles during the period $1857-1862$, from a mean of 0.09. Note that this effect is somewhat larger than the one observed at the municipal level. Here, the fall corresponds to about one fourth of the mean incidence of battles, whereas at the municipality level the size is somewhat below one sixth of the mean. This suggests that there are indeed spillovers in the incidence of battles that we are not capturing at the municipality level, but they are not large.

\subsection{Mechanisms}

We have established that the extension of voting rights in nineteenth century Colombia reduced the level of violence. Municipalities where more voters were enfranchised with the introduction of universal male suffrage observed less violence than those in which

\footnotetext{
${ }^{13}$ While we have 536 municipalities (at the time, distritos parroquiales), there are 114 cantons in our regressions in Table 5 .
} 
there were less new voters.

At some level, this result is somewhat surprising given the perceptions about Colombia's democracy and violence. Indeed, one reading of Colombia's political history and its extraordinarily persistent political parties seems to suggest that political elites in Colombia were constantly trying to avoid war, but had a hard time achieving this. More importantly, the solutions that were "successful" in the twentieth century in terms of reducing violence could be regarded anti-democratic. A prominent example is the incomplete vote and power-sharing institutions of the early twentieth century, which Mazzuca and Robinson (2009) show were key in establishing order after the tumultuous nineteenth century. Perhaps more clearly, the Frente Nacional (National Front) established since the mid-twentieth century helped overcome the period of intense inter-partisan violence known as La Violencia. But, again, it did so via a power-sharing agreement under which the presidency alternated every four years between the Conservative and Liberal parties, with the two parties being allocated half of the executive jobs ${ }^{14}$ These arrangements, of course, excluded other political parties and reduced political competition.

Also in line with the idea that "too much democracy" led to violence in Colombia, one common claim is that elections in Colombia polarized politics, and were often proximate determinants of rebellions (Posada-Carbó, 1995). Bushnell (1993) writes that "elections, though regularly held, were almost always marked by scattered incidents of violence in the back country and by charges of fraud that were often well founded." In 1879, in the newspaper Diario de Cundinamarca, the following description could be found: "elections in Colombia are real confrontations, and terrible confrontations of press, agitation, intrigue, letters, bribes, weapons, vengeance incentives, politics, choler, menace" Guerra, 1922 , p.608).

These notions about the connection between democracy and violence in Colombia are probably also fueled by the clear indication that, in the Latin American context, Colombia is both extraordinarily democratic and extraordinarily violent. As Deas (1993) puts it "the periods of authoritarianism or militarism have been very scarce and very short in the one hundred and forty years of Colombia's existence as independent state. There have been numerous constitutional experiments, and this republic has had more elections, under more systems, central and federal, direct and indirect, hegemonic and proportional, and with more consequences than any American or European country that could attempt to dispute the title." The PolityIV democracy index, as depicted in Figure 2, confirms that Colombia has been relatively democratic in the Latin American context. Needless to say, Colombia has also been relatively violent in the region. This is confirmed by the years in conflict since World War II, according to the UCDP/PRIO Civil War dataset (see Table 6).

Discussing twentieth-century violence in Colombia, authors like Pecaut (1984) have

\footnotetext{
${ }^{14}$ The National Front has been extensively studied. See, for example, Hartlyn (1988).
} 
argued that this dual condition is no coincidence. He asks: "Should we consider as pure coincidence this dual continuity-civil democracy, on the one hand, and social violence and guerrilla warfare, on the other? [My hypothesis] is that it is not merely coincidental. Violence is the flip side of Colombian democracy." However, when looking into the reasons for this relation, it becomes apparent that it is the lack of representativeness of Colombia's democracy, not the fact that Colombia is too democratic, what is hypothesized to be driving the connection. Pecaut (1984) thinks that Colombia remains "halfway in the establishment of political democracy. It certainly recognizes universal suffrage [but] it has been a manifestation of the immutable division between the two identities -Liberal and Conservative-". Moreover the rivalry between these two identities, strengthened after bipartisan conflict, "had nothing to do with the social stakes. Under these conditions, the social conflicts were doomed to unfold on another stage."

Hence, perhaps just as in the twentieth century the lack of representativeness of the democratic institutions led to protracted guerrilla warfare in Colombia, the lack of political rights in the nineteenth-century exacerbated violence. Our results clearly suggest that this was the case. But, to better understand some of the channels at play, we next perform a set of additional exercises.

First, in Table 7, we look at which components of the proportion of new voters in 1853 explain the results. Specifically, instead of interacting new.voters with the 18571862 dummy, we independently interact each of its components (the municipal shares of married slaves, young and single free men, old and single free men, and married free men). We do so separately, in columns 1-4, and including all components with their interactions in column 5. These regressions include differential trends as functions of observable characteristics and a full set of municipality and year fixed effects.

The results show that the effect of new.voters is accounted for by married free men, regardless of their age. Instead, neither slaves nor old single men explain the effect of new voters on violence. Old and young single men are a small proportion of the population in most municipalities, so this lack of an effect is perhaps not surprising. In turn, the fact that the proportion of slaves plays a small role is both reassuring about the validity of the identification assumption and falls in line with Colombian historiography on the causes of the nineteenth-century civil wars. It is reassuring because places with many slaves tended to be very different to places with few slaves. If all the effect was coming from the comparison between these two types of places, we would be worried that other omitted variable connected with the slave economy could explain the differences between municipalities. And it falls in line with the historical record because the civil wars of the nineteenth century have mostly been depicted as fights between political elites, not as violence around emancipation or other economic vindications by excluded slaves. Also, that the bulk of free men (married individuals of any age) drives the results is in line with the idea that this segment of the population plausibly includes the people who were 
most politically active at the time.

Finally, that youngsters do not drive the results is also reassuring of the identification assumption. If our results were mainly driven by young men, a potential concern is that we are just picking up a differential behavior between municipalities with different availability of fighters in a period of escalating national violence, for reasons unrelated with the changes in the electoral rules.

A second set of exercises is reported in Table 8. This table splits the sample according to several characteristics of municipalities, in order to explore which kinds of municipalities experienced a greater payoff (in terms of less violence) when the franchise was extended. In particular, we look at two key municipal characteristics: the degree of political competition and the extent of state capacity. In column 1, we run the regression for the set of municipalities in which the extent of political competition is above the mean (with competition captured by an inverse measure of the vote margin between the first and second most-voted candidate in the municipality during the 1856 presidential elections). Column 2, instead, runs the same regression for municipalities in the leastcompetitive municipalities (below the mean). We find that in competitive municipalities the interaction of the 1857-1862 dummy and new voters is negative and significant unlike what happens in non-politically competitive municipalities.

Moving to proxies for the extent of state capacity in each municipality, in columns 3 and 4 we split the sample according to the age of each municipality (places older than the mean are included in column 3, and younger municipalities in column 4). Older municipalities are likely to have a more consolidated presence of the state, and so this is a crude but useful proxy for state strength at the local level. To measure institutions more directly, in columns 5 and 6 we split the sample using the index for colonial institutions explained in section 2, Column 5 includes the set of municipalities with some colonial institutions, and column 6 those municipalities without. Again, we associate the latter with less local state capacity. In both cases, the results clearly point out that only in municipalities with greater state capacity (columns 3 and 5) the interaction of the 18571862 dummy and new voters is significant and negative.

Hence, the impact of new voters is stronger in places with stronger state institutions and with more political competition. We interpret both of these results as suggesting that violence in nineteenth-century Colombia was essentially a technology for political elites to compete for the rents from power. In Colombia, these elites were represented by the enduring Liberal and Conservative parties. There is considerable consensus that violence was largely between parties, but that differences between parties were small, except on ecclesiastic issues and federalism. As Bushnell (1984) asks, "if there were, then, no substantial differences on policy between the two parties, save in ecclesiastical matters, why were Colombian political contests so hard-fought, even violent?" (p. 27). He replies: "political struggles in Colombia revolved around competition for control of 
the bureaucratic positions, that is, for the meager booty contained in the public treasury or simply for the social status that official positions conferred" (p. 27). Politicians were quite aware of this cause of struggle. For instance, one of the reasons why Liberal leader Manuel Murillo Toro defended fiscal federalism had to do with the idea that "this was not simply a fiscal measure (...) by weakening the power of the central government, it would also attenuate the main cause of bipartisan struggle: the passion to control the jobs and clientelism of the national government" (Palacios \& Safford, 2002, p. 389).

In short, the main cause of political violence was arguably the fight to control the rents from power. If these was the driver of violence, we expect (as we find in our data) that if elections could serve to substitute for violence then places were elections are most strengthened (because more people gain the right to vote) should have less violence especially if the contest for power is tight enough (political competition) and if the prize for winning the contest is attractive enough (state capacity).

It is important to emphasize once more that the statement stemming from our results is conditional and somewhat subtle: given there are elections, we find that there is less violence if more people can participate in them. There are several possible and related reasons why this effect could arise. First, with more participation, elections are more legitimate, and democracy becomes a more widely accepted set of rules for allocating power, reducing violence. Second, and quite relevant for the Colombian case, electoral fraud (casting votes for those who were not allowed to vote) in elections is often a proximate cause of violence. This cause is eliminated or at least attenuated by permitting participation of more citizens. Indeed, a very common form of electoral fraud is stuffing ballots of those ineligible to vote. One may think that this channel operates mainly during elections, but it could also be relevant off-election periods. In particular, politically active people may be less willing to get involved in violence if they anticipate to take part in electoral politics and if they expect elections not to be fraudulent.

\section{Conclusion}

In spite of all the theoretical attention, empirically studying the relationship between democracy and conflict presents an enormous challenge. 'Democracy' is a complex, multidimensional concept, and the usual endogeneity concerns are particularly pressing in regressions of violence on measures of democracy.

This paper takes advantage of an experiment of history to examine the impact of one simple, measurable dimension of democracy (the size of the franchise) on conflict, while at the same time attempting to overcome the identification problem. In 1853, Colombia established universal male suffrage. Using a simple difference-in-differences specification at the municipal-level, we find that municipalities where more voters were enfranchised relative to their population had fewer violent battles while this enfranchisement was in 
effect.

Our interpretation of the results is that, in democracies where violence is a technology whereby competing factions try to control the rents from power, strengthening democratic institutions via an extension of voting rights may help reduce the use of violence. In this context, elections may gain legitimacy and proximate causes of political violence such as fraud will be muted, decreasing the use of violence especially where citizens are politically active, where political competition is stiff, and where the rents from power are larger.

In the case of Colombia, violence in the nineteenth century was largely between parties, and revolved around competition for control of the bureaucratic positions and rents from power more than around ideological differences. If elections substituted violence in this context, the franchise extension should have a larger effect in those areas where politically active citizens formed the majority of new voters, where competition between parties was stiffer, and where rents from government where larger. This is, indeed, what we found. 


\section{References}

Abadie, A. (2004, October). Poverty, political freedom, and the roots of terrorism (Working Paper No. 10859). National Bureau of Economic Research.

Acemoglu, D., \& Robinson, J. A. (2006). Economic origins of dictatorship and democracy. New York, NY: Cambridge University Press.

Angrist, J., \& Pischke, J. (2009). Mostly harmless econometrics: an empiricist's companion. Princeton, N.J.: Princeton University Press.

Bernard, O., \& Zambrano, F. (1993). Ciudad y territorio: El proceso de poblamiento en Colombia. Bogotá: Academia de Historia de Bogotá.

Bushnell, D. (1970). Elecciones presidenciales Colombianas, 1825-1856. In M. Urrutia \& M. Arrubla (Eds.), Compendio de estadísticas históricas en Colombia. Bogotá: Universidad Nacional de Colombia.

Bushnell, D. (1984). Politics and violence in nineteenth century Colombia. In R. P. naranda \& G. Sánchez (Eds.), Violence in Colombia: The contemporary crisis in historical perspective. Wilmington, DE: Scholarly Resources Books.

Bushnell, D. (1993). The making of modern Colombia: A nation in spite of itself. Berkeley: University of California Press.

Chacón, M., Robinson, J. A., \& Torvik, R. (2011). When is democracy an equilibrium? theory and evidence from Colombias La Violencia. Journal of Conflict Resolution, $55(3), 366-396$.

Davenport, C. (1997). From ballots to bullets: an empirical assessment of how national elections influence State uses of political repression. Electoral Studies(4), 517-541.

Davenport, C. (2007). State repression and the domestic democratic peace. Cambridge University Press.

Deas, M. (1993). Algunas notas sobre el caciquismo en Colombia. In Del poder y la gramática y otros ensayos sobre historia, política y literatura colombianas. Bogotá: Tercer Mundo Editores.

Durán y Díaz, J. (1794). Estado general de todo el Virreinato de Santafé de Bogotá. Bogotá.

Eifert, B., Miguel, E., \& Posner, D. N. (2010). Political competition and ethnic identification in Africa. American Journal of Political Science, 54(2), 494-510.

García-Jimeno, C. (2005). Colonial institutions and long-run economic performance in Colombia: Is there evidence of persistence? (Documentos Cede No. 002152). Bogotá: Universidad de los Andes-Cede.

Gómez, F. (1969). Análisis de los censos de población del siglo XIX en Colombia (Tech. Rep.). Bogotá: Universidad de los Andes.

Guerra, J. J. (1922). Viceversas liberales. Documentos relativos a la historia del liberalismo colombiano. Bogotá: Editorial La Cruzada. 
Hartlyn, J. (1988). The politics of coalition rule in Colombia. Cambridge: Cambridge University Press.

IGAC. (2002). Caminos Reales en el Nuevo Reino de Granada (map). Instituto Geográfico Agustín Codazzi. (Sources: Robert West, 1952; Alberto Pardo, 1972; Atlás Histórico Nacional, 1790)

Mazzuca, S. L., \& Robinson, J. A. (2009). Political conflict and power sharing in the origins of modern Colombia. Hispanic American Historical Review(2), 285-321.

Palacios, M., \& Safford, F. (2002). Colombia: país fragmentado, sociedad dividida. Bogotá: Editorial Norma.

Pecaut, D. (1984). Guerrillas and violence. In Violence in Colombia: The contemporary crisis in historical perspective. Wilmington, DE.: Scholarly Resources Books.

Posada-Carbó, E. (1995). Civilizar las urnas 1830-1930. Boletín cultural y bibliográfico(39), 3-25.

Riascos Grueso, E. (1950). Geografía guerrera de Colombia. Impr. Bolivariana.

Tovar, J. (2007, November). La manumisión en Colombia: 1821 -1851. Un análisis cuantitativo (Documentos CEDE). Universidad de los Andes-CEDE. 
Figure 1: XIXth-century Battles in Colombia Yearly average of municipal number of battles, by level of new voters

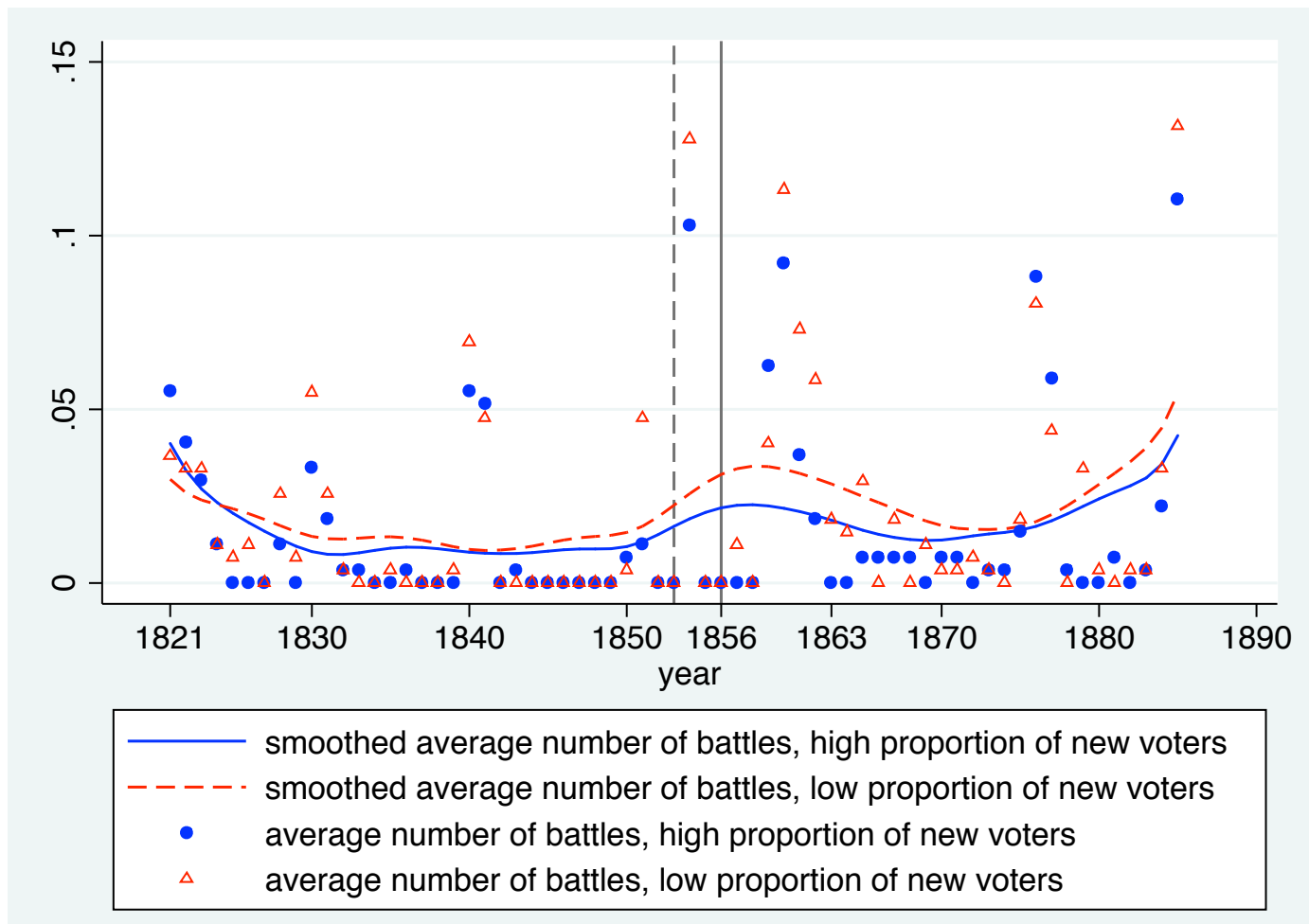

Note: Municipalities with a high proportion of voters are those for which the proxy for new voters (as \% of population) in 1853 is above the median (and the rest are classified in the low proportion categories). The smoothed battles lines correspond to a locally weighted regression of the average number of battles on year (with a 0.4 bandwidth). Vertical lines are shown for 1853 (dashed, when the Constitution extending the franchise was enacted) and 1856 (solid, when the first presidential election with universal male suffrage and direct voting took place). 
Figure 2: Polity IV Index since Independence for a sample of Latin American countries
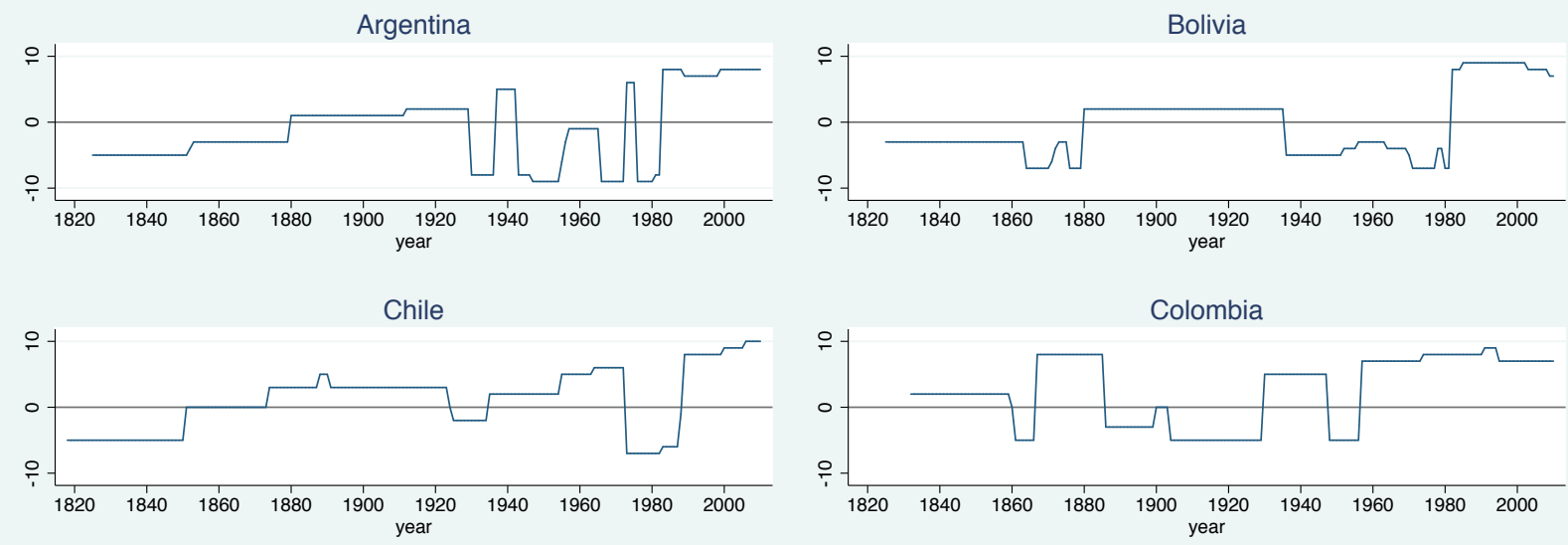

Salvador
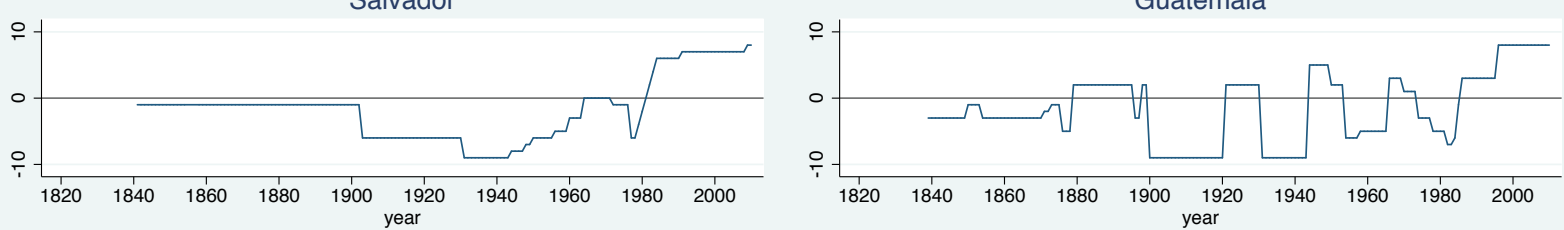

Peru
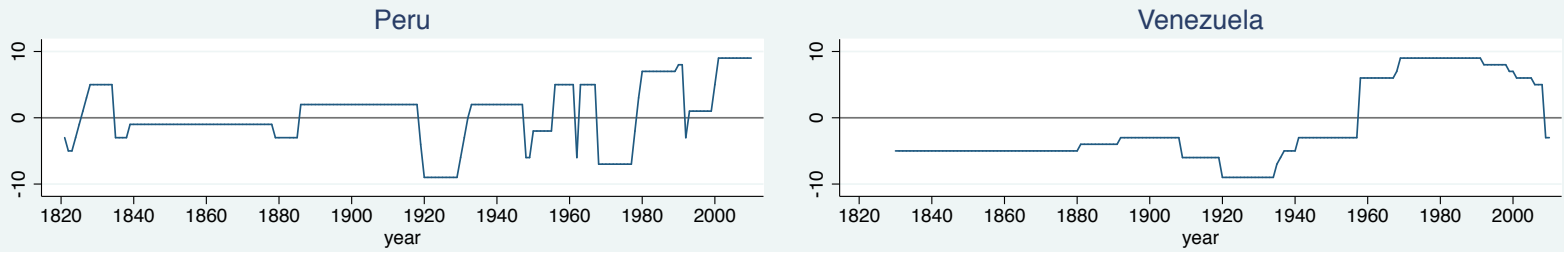

Note: Polity IV democracy index (polity2) for the set of displayed countries (-10=least democratic, $10=$ most democratic). 
Table 1: Summary statistics

\begin{tabular}{|c|c|c|c|c|c|}
\hline & Mean & Std. Dev. & Min. & Max. & $\mathbf{N}$ \\
\hline Share of new voters (in \%), 1851 census & 25.32 & 4.17 & 15.16 & 53.15 & 536 \\
\hline Share of new voters (in \%), 1851 census (canton level) & 25.06 & 3.37 & 19.10 & 46.35 & 114 \\
\hline Share of new voters (in \%), 1843 census & 24.39 & 3.11 & 15.24 & 44.8 & 498 \\
\hline Battles (whole sample) & 0.02 & 0.14 & 0 & 4 & 35,035 \\
\hline Battles (high prop. of new voters) & 0.02 & 0.13 & 0 & 3 & 13,325 \\
\hline Battles (low prop. of new voters) & 0.02 & 0.15 & 0 & 4 & 21,710 \\
\hline Battles 1857-1862 (whole sample) & 0.04 & 0.23 & 0 & 4 & 3234 \\
\hline Battles 1857-1862 (high prop. of new voters) & 0.04 & 0.21 & 0 & 2 & 1,230 \\
\hline Battles 1857-1862 (low prop. of new voters) & 0.05 & 0.24 & 0 & 4 & 2,004 \\
\hline Battles (canton level, whole sample) & 0.09 & 0.38 & 0 & 6 & 7,410 \\
\hline \multicolumn{6}{|l|}{ Controls: } \\
\hline 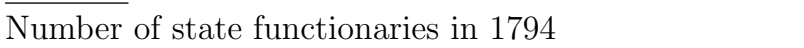 & 10.54 & 169.27 & 0 & 3844 & 536 \\
\hline State presence index in 1794 & 0.88 & 0.98 & 0 & 4 & 536 \\
\hline Dummy $=1$ if Ospina won in 1856 & 0.5 & 0.5 & 0 & 1 & 536 \\
\hline Primary rivers density $(\mathrm{kms} / \mathrm{Km} 2)$ & 36.18 & 307.64 & 0 & 6467.87 & 536 \\
\hline Secondary rivers density (kms/Km2) & 18.57 & 45.69 & 0 & 760.64 & 536 \\
\hline Terciary rivers density (kms/Km2) & 14.64 & 30.62 & 0 & 237.32 & 536 \\
\hline Minimum distance to Royal road (kms) & 15.74 & 17.83 & 0.04 & 120.29 & 536 \\
\hline Altitude, municipality center & 1380.51 & 926.36 & 2 & 3087 & 536 \\
\hline
\end{tabular}

Note: See Appendix Table A-1 for variable definition and sources. Battles for 1821-1885. High (low) proportion of new voters is the subsample where the estimated enfranchised population is above (below) the mean proportion of new voters (as measured by the 1851 census). Excepted when measured at the canton level (an agglomeration of municipalities), battles vary by municipality and year, and the remaining variables vary only by municipality. 
Table 2: Democratization and Violence New voters and battles after the 1853 reform

Dependent variable: Battles, 1821-1885

(1)

$(2)$

(3)

\begin{tabular}{lcccc} 
Prop. new voters & $-0.000600^{* *}$ & $-0.000623^{* *}$ & & \\
& $(0.000272)$ & $(0.000292)$ & & \\
& $0.0581^{* * *}$ & & & \\
1854 - 1862 & $(0.0223)$ & & & \\
& -0.00123 & & & \\
New voters x 1854 - 1862 & $(0.000838)$ & & & \\
& & $0.0673^{* * *}$ & & \\
1857 - 1862 & & $(0.0227)$ & & \\
& & $-0.00160^{*}$ & $-0.00160^{*}$ & $-0.00147^{*}$ \\
New voters x 1857 - 1862 & & $(0.000829)$ & $(0.000836)$ & $(0.000822)$ \\
& & & & \\
& & & & Yes \\
Controls & & & & Yes \\
Municipality \& time FE & & & & \\
Controls x 1857-1862 & 35,035 & 35,035 & 35,035 & 35,035 \\
& 536 & 536 & 536 & 536 \\
Observations & 0.005 & 0.004 & 0.093 & 0.095 \\
Municipalities & & & & \\
R-squared & & & & \\
\hline \hline
\end{tabular}

Ordinary Least Squares regressions. Robust standard errors clustered at the municipal level in parentheses. $*$ is significance at the $10 \%$ level, $* *$ is significance at the $5 \%$ level, $* * *$ is significance at the $1 \%$ level. Controls in columns 4 include geographic controls (distance to royal road, river density, altitude), electoral controls (indicator of support for Ospina, the conservative candidate, in the 1856 presidential elections), and historical institutional controls (the number of colonial functionaries and an index of presence of colonial institutions in each municipality). See Appendix Table A-1 for variable definition and sources. 


\section{Table 3: Robustness: Controlling for Previous Constitutional Changes}

\begin{tabular}{|c|c|c|c|c|c|}
\hline Dependent variable: I & $\begin{array}{l}\text { cidence of } \mathrm{b} \\
\text { (1) }\end{array}$ & $\begin{array}{l}\text { tttles, } 1821-1 \\
\text { (2) }\end{array}$ & 885 (3) & (4) & $(5)$ \\
\hline \multicolumn{6}{|l|}{ New voters $\mathrm{x} . .}$. \\
\hline ...1857-1862 & $\begin{array}{l}-0.00147^{*} \\
(0.000822)\end{array}$ & & & $\begin{array}{l}-0.00143^{*} \\
(0.000835)\end{array}$ & $\begin{array}{l}-0.00146^{*} \\
(0.000836)\end{array}$ \\
\hline ...1833-1842 & & $\begin{array}{c}0.000188 \\
(0.000372)\end{array}$ & & $\begin{array}{c}5.80 \mathrm{e}-05 \\
(0.000384)\end{array}$ & $\begin{array}{c}2.18 \mathrm{e}-05 \\
(0.000391)\end{array}$ \\
\hline ...1844-1855 & & & $\begin{array}{c}0.000265 \\
(0.000323)\end{array}$ & $\begin{array}{c}0.000114 \\
(0.000363)\end{array}$ & $\begin{array}{c}7.81 \mathrm{e}-05 \\
(0.000371)\end{array}$ \\
\hline Post 1863 increase & & & & & $\begin{array}{c}-0.0146 \\
(0.00959)\end{array}$ \\
\hline Post 1863 decrease & & & & & $\begin{array}{c}0.0110^{* * *} \\
(0.00356)\end{array}$ \\
\hline Mun. \& time FE & Yes & Yes & Yes & Yes & Yes \\
\hline Controls x 1857-1862 & Yes & Yes & Yes & Yes & Yes \\
\hline Observations & 35,035 & 35,035 & 35,035 & 35,035 & 35,035 \\
\hline Municipalities & 536 & 536 & 536 & 536 & 536 \\
\hline R-squared & 0.095 & 0.095 & 0.095 & 0.095 & 0.096 \\
\hline
\end{tabular}

Ordinary Least Squares regressions. Robust standard errors clustered at the municipal level in parentheses. $*$ is significance at the $10 \%$ level, $* *$ is significance at the $5 \%$ level, $* * *$ is significance at the $1 \%$ level. Controls (interacted with the 1857-1862 dummy) as in Table 2, column 4. Full set of municipality and year fixed effects in all columns. 'Post 1863 increase' equals one for municipalities in states were voting rights unambiguously increased further in 1863 (Magdalena) and 'Post 1863 decrease', equals one for municipalities in states were voting rights unambiguously decreased further in 1863 (Tolima and Boyacá). See Appendix Table A-1 for variable definition and sources. 
Table 4: Democratization and Violence

Proportion of new voters according to the 1843 census

\begin{tabular}{|c|c|c|c|c|c|}
\hline \multicolumn{6}{|c|}{ Dependent variable: Battles, 1821-1885 } \\
\hline & (1) & (2) & $(3)$ & (4) & $(5)$ \\
\hline Prop. new voters & $\begin{array}{c}-0.00140^{* * *} \\
(0.000498)\end{array}$ & $\begin{array}{c}-0.00169 * * * \\
(0.000514)\end{array}$ & & & \\
\hline $1854-1862$ & $\begin{array}{c}0.170 * * * \\
(0.0408)\end{array}$ & & & & \\
\hline New voters x 1854 - 1862 & $\begin{array}{c}-0.00580^{* * *} \\
(0.00158)\end{array}$ & & & & \\
\hline $1857-1862$ & & $\begin{array}{c}0.163^{* * *} \\
(0.0478)\end{array}$ & & & \\
\hline New voters x $1857-1862$ & & $\begin{array}{c}-0.00557^{* * *} \\
(0.00186)\end{array}$ & $\begin{array}{c}-0.00557^{* * *} \\
(0.00188)\end{array}$ & $\begin{array}{c}-0.00434^{* *} \\
(0.00176)\end{array}$ & $\begin{array}{c}-0.00429^{* *} \\
(0.00176)\end{array}$ \\
\hline Post 1863 increase & & & & & $\begin{array}{c}-0.000957 \\
(0.0185)\end{array}$ \\
\hline Post 1863 decrease & & & & & $\begin{array}{c}0.0113^{* * *} \\
(0.00382)\end{array}$ \\
\hline \multicolumn{6}{|l|}{ Controls } \\
\hline Municipality \& time FE & & & Yes & Yes & Yes \\
\hline Controls x 1857-1862 & & & & Yes & Yes \\
\hline Observations & 32,500 & 32,500 & 32,500 & 32,500 & 32,500 \\
\hline Municipalities & 498 & 498 & 498 & 498 & 498 \\
\hline R-squared & 0.008 & 0.006 & 0.097 & 0.099 & 0.099 \\
\hline
\end{tabular}

Ordinary Least Squares regressions. Robust standard errors clustered at the municipal level in parentheses. ${ }^{*}$ is significance at the $10 \%$ level, ${ }^{* *}$ is significance at the $5 \%$ level, $* * *$ is significance at the $1 \%$ level. Controls in columns 4 and 5 include geographic controls (distance to royal road, river density, altitude), electoral controls (indicator of support for Ospina, the conservative candidate, in the 1856 presidential elections), and historical institutional controls (the number of colonial functionaries and an index of presence of colonial institutions in each municipality). See Appendix Table A-1 for variable definition and sources. 
Table 5: Canton-level regressions

Dependent variable: Incidence of battles, 1821-1885

(1)

N. voters x $1857-1862$

$-0.00647^{*}$

$-0.00749^{*}$

$(0.00377)$

$(0.00395)$

Canton \& time FE

Yes

Yes

Controls x 1857-1862

Yes

\begin{tabular}{lcc} 
Observations & 7,410 & 7,410 \\
Cantons & 114 & 114 \\
R-squared & 0.185 & 0.190 \\
\hline
\end{tabular}

Ordinary Least Squares regressions at the province level. Robust standard errors clustered at the province level in parentheses. ${ }^{*}$ is significance at the $10 \%$ level, ${ }^{* *}$ is significance at the $5 \%$ level, ${ }^{* * *}$ is significance at the $1 \%$ level. Controls as in Table 2 , columns 4-5. See Appendix Table A-1 for variable definition and sources. 
Table 6: Years in conflict, 1946-2005

\begin{tabular}{lc}
\hline \hline & \\
Country: & Years in conflict \\
\hline Argentina & 7 \\
Bolivia & 3 \\
Chile & 1 \\
Colombia & 40 \\
El Salvador & 14 \\
Guatemala & 33 \\
Peru & 21 \\
Venezuela, RB & 2 \\
\hline \hline
\end{tabular}

Note: Years in conflict over the 1946-2005 period according to the UCDP/PRIO Armed Conflict Dataset. 
Table 7: Mechanisms I: Components of 'proportion of new voters'

\begin{tabular}{|c|c|c|c|c|c|}
\hline Dependent variable: Incidence of battles & $\begin{array}{c}1821-1885 \\
(1)\end{array}$ & $(2)$ & (3) & (4) & $(5)$ \\
\hline N. voters-married slaves $\mathrm{x}$ 1857-1862 & $\begin{array}{c}0.0155^{*} \\
(0.00826)\end{array}$ & & & & $\begin{array}{c}0.0131 \\
(0.00841)\end{array}$ \\
\hline N. voters-young sing. free $\mathrm{x}$ 1857-1862 & & $\begin{array}{l}-0.000407 \\
(0.000868)\end{array}$ & & & $\begin{array}{l}-0.000903 \\
(0.000939)\end{array}$ \\
\hline N. voters-old sing. free $\mathrm{x}$ 1857-1862 & & & $\begin{array}{c}0.00166 \\
(0.00389)\end{array}$ & & $\begin{array}{c}0.00200 \\
(0.00343)\end{array}$ \\
\hline N. voters-married free x 1857-1862 & & & & $\begin{array}{l}-0.00404^{* * *} \\
(0.00112)\end{array}$ & $\begin{array}{c}-0.00409^{* * *} \\
(0.00122)\end{array}$ \\
\hline Mun. \& time FE & Yes & Yes & Yes & Yes & Yes \\
\hline Controls x 1857-1862 & Yes & Yes & Yes & Yes & Yes \\
\hline Observations & 35,035 & 35,035 & 35,035 & 35,035 & 35,035 \\
\hline Municipalities & 536 & 536 & 536 & 536 & 536 \\
\hline R-squared & 0.095 & 0.095 & 0.095 & 0.096 & 0.096 \\
\hline
\end{tabular}

Ordinary Least Squares regressions. Robust standard errors clustered at the municipal level in parentheses. Controls (interacted with the 1857-1862 dummy) are as in Table 2, column 4. See Appendix Table A-1 for variable definition and sources. 
Table 8: Mechanisms II: Political competition, Age of municipality, Colonial institutions

\begin{tabular}{|c|c|c|c|c|c|c|}
\hline \multicolumn{7}{|c|}{ Dependent variable: Incidence of battles, $1821-1885$} \\
\hline & $(1)$ & $(2)$ & \multirow{2}{*}{\multicolumn{2}{|c|}{$\begin{array}{l}(3) \\
\text { Age of municipality }\end{array}$}} & \multirow{2}{*}{\multicolumn{2}{|c|}{$\begin{array}{l}(5) \\
\text { Colonial institut. }\end{array}$}} \\
\hline & \multicolumn{2}{|c|}{ Political Comp. } & & & & \\
\hline & High & Low & Old & New & Yes & No \\
\hline N. voters x 1857-1862 & $\begin{array}{c}-0.00221 * \\
(0.00125)\end{array}$ & $\begin{array}{r}-0.000596 \\
(0.00104)\end{array}$ & $\begin{array}{c}-0.00334^{* *} \\
(0.00146)\end{array}$ & $\begin{array}{l}-0.000426 \\
(0.000989)\end{array}$ & $\begin{array}{r}-0.00202^{*} \\
(0.00105)\end{array}$ & $\begin{array}{l}0.000844 \\
(0.00119)\end{array}$ \\
\hline Mun. \& time FE & Yes & Yes & Yes & Yes & Yes & Yes \\
\hline Controls x 1857-1862 & Yes & Yes & Yes & Yes & Yes & Yes \\
\hline Observations & 15,145 & 19,890 & 14,495 & 20,540 & 20,475 & 14,560 \\
\hline Municipalities & 231 & 305 & 221 & 315 & 313 & 223 \\
\hline R-squared & 0.118 & 0.076 & 0.120 & 0.078 & 0.110 & 0.072 \\
\hline
\end{tabular}

Ordinary Least Squares regressions. Robust standard errors clustered at the municipal level in parentheses. $*$ is significance at the $10 \%$ level, $* *$ is significance at the $5 \%$ level, $* * *$ is significance at the $1 \%$ level. High and low competition and old and new municipalities are defined in terms of the mean in the sample. Controls (interacted with the 1857-1862 dummy) are as in Table 2, column 4. See Appendix Table A-1 for variable definition and sources. 
Table A-1: Variables and sources

\begin{tabular}{|c|c|c|c|}
\hline Variable & Description & \multicolumn{2}{|l|}{ Source } \\
\hline No. of Battles & No. of battles in each municipality and year, 1821-1885 & \multicolumn{2}{|l|}{ Riascos Grueso 1950, } \\
\hline New voters & $\begin{array}{l}\text { Proxy for the new franchise. Single men } 16+\text { in } 1851 \text { ( } 21 \text { by } 1856 \text { ), married men, } \\
\text { and married slaves (as a } \% \text { of total municipal population) }\end{array}$ & \multicolumn{2}{|l|}{1851 Census } \\
\hline $\begin{array}{l}\text { Young single } \\
\text { free men }\end{array}$ & Single men ages $16-50$ in 1851 (in \%) & \multicolumn{2}{|l|}{1851 Census } \\
\hline $\begin{array}{l}\text { Old single } \\
\text { free men }\end{array}$ & Single men ages $50+$ in 1851 (in \%) & \multicolumn{2}{|l|}{1851 Census } \\
\hline Married slaves & Married slaves in 1851 (in \%) & \multicolumn{2}{|l|}{1851 Census } \\
\hline Married free men & Married men in 1851 (in \%) & \multicolumn{2}{|l|}{1851 Census } \\
\hline Pol. competition & $1-\frac{\text { votes first-votes second }}{\text { votes first }+ \text { votes second }}$, with votes from the 1856 presidential election & \multicolumn{2}{|l|}{ Bushnell (1970) } \\
\hline Ospina Winner & $\begin{array}{l}\text { Dummy }=1 \text { if Ospina, the conservative candidate, obtained the majority of votes in } \\
\text { each municipality in the } 1856 \text { presidential election }\end{array}$ & \multicolumn{2}{|l|}{ Bushnell (1970) } \\
\hline $\begin{array}{l}\text { Age of municipality } \\
\text { New and old munici- } \\
\text { pality }\end{array}$ & age $=1856-$ foundation date, Old municipallity is $>100$ years & Bernard and Zambrano & (1993) \\
\hline $\begin{array}{l}\text { Colonial Institutions } \\
\text { Index }\end{array}$ & $\begin{array}{l}\text { State Capacity Index (0-4): count of tobacco estanco, aguardiente estanco, mail } \\
\text { service and alcabala. }\end{array}$ & \multicolumn{2}{|l|}{$\begin{array}{l}\text { García-Jimeno 2005 } \\
\text { based on Durán y Díaz } \\
\text { (1794. }\end{array}$} \\
\hline $\begin{array}{l}\text { Number of colonial } \\
\text { functionaries }\end{array}$ & $\begin{array}{l}\text { Full account of the Colonial State bureaucracy, coding all the crown employees in } \\
\text { each city, villa or town; match to the municipalities in our sample }\end{array}$ & \multicolumn{2}{|l|}{$\begin{array}{l}\text { García-Jimeno 2005 } \\
\text { based on Durán y Díaz } \\
1794\end{array}$} \\
\hline $\begin{array}{l}1863 \text { increase \& } \\
1863 \text { decrease }\end{array}$ & $\begin{array}{l}\text { Dummy }=1 \text { if } 1863 \text { State Constitution increased (decreased) franchise in State } s \text { in } \\
1863 \text {, and zero otherwise }\end{array}$ & \multicolumn{2}{|l|}{$\begin{array}{l}1863 \text { State Constitu- } \\
\text { tions }\end{array}$} \\
\hline $\begin{array}{l}\text { Distance to } \\
\text { royal roads }\end{array}$ & Distance from the centroid of each municipality to the nearest royal road & \multicolumn{2}{|l|}{ 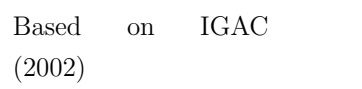 } \\
\hline Altitude & Altitude above sea level, in meters, of the urban center of each municipality & \multicolumn{2}{|l|}{$\begin{array}{l}\text { CEDE, Universidad } \\
\text { de los Andes }\end{array}$} \\
\hline Rainfall & Mean annual rainfall level in each municipality & \multicolumn{2}{|l|}{$\begin{array}{l}\text { CEDE, Universidad } \\
\text { de los Andes }\end{array}$} \\
\hline $\begin{array}{l}\text { Density of primary, } \\
\text { secondary and tertiary } \\
\text { rivers }\end{array}$ & $\begin{array}{l}\text { Quotient between the longitude of each kind of river in meters and the surface area } \\
\text { of each municipality in square kilometers }\end{array}$ & \multicolumn{2}{|l|}{$\begin{array}{l}\text { Colombian Geograph- } \\
\text { ical Institute (IGAC) }\end{array}$} \\
\hline
\end{tabular}

